\title{
Lipid composition of the giant lion's-paw scallop (Nodipecten subnodosus) in relation to gametogenesis I. Fatty acids
}

\author{
E. Palacios ${ }^{a^{*}}$, I.S. Racotta ${ }^{a}$, E. Kraffe ${ }^{b}$, Y. Marty ${ }^{b}$, J. Moal ${ }^{c}$ and J.F. Samain ${ }^{c}$ \\ ${ }^{a}$ Centro de Investigaciones Biológicas del Noroeste (CIBNOR), Mar Bermejo 195, Col. Playa Palo de Santa Rita, \\ La Paz, BCS 23090, Mexico \\ ${ }^{\mathrm{b} U M R}$ CNRS 6521, Université de Bretagne Occidentale, CS 3837, Brest 29238, France \\ 'IFREMER, Centre de Brest, Laboratoire de Physiologie des Mollusques, BP 70, Plouzané 29280, France \\ *: Corresponding author : Tel.: +52 612123 8508; fax: +52 612125 3625. epalacio@cibnor.mx
}

\begin{abstract}
Seasonal variations in fatty acid composition in several tissues of a 1-year-old population of giant lion's-paw scallop Nodipecten subnodosus were analyzed during gonad development. Samples were taken bimonthly from December 1999 to June 2000, a period in which gonad development was occurring. Fatty acid accumulation in neutral and polar lipids of the female gonad was concomitant to the gonad development and presented a maximum in June. Among essential fatty acids, a specific accumulation was observed only for $20: 5 n-3$ in the female gonad, as suggested by an increase in its proportion in the neutral and the polar fractions. However, no specific accumulation was observed for $22: 6 n-3$, as its proportion remained relatively constant in both fractions. We suggest that a specific increase of 22:6n - 3 is not necessary during gametogenesis because its proportion was high enough for reproductive purposes (20-30\%). Although some data suggest a partial mobilization of polyunsaturated fatty acids from the muscle and digestive gland to the female gonad during gonad development, the main supply came directly from the diet. The maximum increase in total and specific fatty acids in the digestive gland occurred in April and was maintained in June. These changes reflect either a higher lipid availability of the food, or the beginning of storage process in the digestive gland. However, in the female gonad, the maximum increase was observed in June, whereas gonad development and spawning were observed from April. It is suggested that different patterns of lipid accumulation in the first (April) and second (June) maturation processes could be related to the reproductive cycle of this species, which exhibits an initial facultative maturation during spring and the main reproductive activity during summer.
\end{abstract}

Keywords: Arachidonic acid; DHA; EPA; HUFA; Pectinidae; Reproduction 
1

2

3

4

5

6

7

8

9

\section{Introduction}

Accumulation of lipids in female gonads during gametogenesis is well documented for several species of pectinids (Thompson, 1977; Pazos et al., 1996; Ruiz-Verdugo et al., 2001; Racotta et al., 2003). There are two postulated mechanisms by which pectinids accumulate lipids in the female gonads during maturation: (1) Transfer of lipids from the digestive gland to the gonads (Vasallo, 1973; Barber and Blake, 1981; Epp et al., 1988; Pazos et al., 1997), and (2) Lipogenesis from carbohydrates stored in the muscle, which results in a decrease of muscle carbohydrates during gametogenesis (Beninger and Lucas, 1984; Barber and Blake 1985; Mathieu and Lubet, 1993; Pazos et al., 1997; Martínez and Mettifogo, 1998; Ruiz-Verdugo et al., 2001). Synthesis de novo of saturated fatty acids, either directly in the gonads or in other tissues, was proposed previously by Soudant et al. (1996a). However, mollusks have a limited capacity for elongation and desaturation of long-chain polyunsaturated fatty acids (PUFA) (Waldock and Holland, 1984; Chu and Greaves, 1991, Ackman and Kean-Howie, 1995). Thus, PUFA for gonad development are probably obtained directly from diet or indirectly after previous accumulation in the digestive gland or other tissues. The role of diet in comparison to previously stored components has been addressed for general biochemical composition (Barber and Blake, 1981; Beninger and Stephan, 1985; Claere-Boudt and Himmelman, 1996; Roman et al., 1996; Pazos et al., 1997; Luna-González et al., 2000; Racotta et al., 2003), but there are few studies that analyze tissue-specific fatty acid variations in relation to gametogenesis in pectinids (Napolitano and Ackman, 1992; 1993; Caers et al., 2003).

The lion-paw scallop (Nodipecten subnodosus) represents an important fishery resource along the Baja California Pacific Coast in Mexico. The species is distributed from Peru to northern Mexico (Félix-Pico et al., 1999); has high commercial value for human consumption; and promising attempts have been made to implement cultivation (GarcíaDominguez et al., 1992; Morales-Hernández and Cáceres-Martínez,1996; Félix-Pico et al., 
1 1999; Barrios-Ruiz et al., 2003; Racotta et al., 2003). Although reproductive processes

2 have been studied in wild (Reinecke-Reyes, 1996, Arellano-Martínez et al., 2004) and

3 cultivated (Racotta et al., 2003) populations, a better understanding of specific patterns of

4 lipid accumulation in female gonads and possible transfer from other tissues is necessary.

5 Such an approach will be valuable to close the life cycle for this species. In a previous

6 study, we observed that Nodipecten subnodosus can yield adductor muscle of $55 \mathrm{~g}$ after

7 culture for 18 months concomitantly with gonad development without transfer of reserves

8 from other tissues (Racotta et al., 2003). The present study analyzes scallops from the same

9 growout cycle for the fatty acid levels in various tissues during gametogenesis in a one-

10 year-old population of the lion-paw scallop.

\section{Materials and methods}

14 Growout and sampling of scallops used in this study were previously described in

15 Racotta et al. (2003). Briefly, mature wild scallops were collected from Guerrero Negro,

16 B.C.S. and induced to spawn (October 1998) at CIBNOR in La Paz, Mexico. At spat stage,

17 the scallops were transported to the growout area in Rancho Bueno (Bahía Magdalena

18 Lagoon complex, B.C.S.), and grown in Nestier trays at a density of 110 scallops per tray.

19 For lipid analyses, five scallops were collected bimonthly from December 1999 until June

202000 (12 and 18 months old, respectively) and transferred to the laboratory at CIBNOR.

21 Upon arrival, samples of mantle, digestive gland, adductor muscle, and female gonads

22 were stored at $-80^{\circ} \mathrm{C}$. Dissection of male gonads sufficient for lipid analyses was done

23 only in June 2000.

24 Lipids were analyzed at the Université de Bretagne Occidental, France. Lipids

25 were extracted with 2:1 chloroform: methanol according to Bligh and Dyer (1959),

26 and extracts were stored in chloroform in a Teflon-lined screw-cap glass vial at - 
$120^{\circ} \mathrm{C}$ under a nitrogen atmosphere until further analysis. Neutral and polar lipid

2 fractions were separated in a silica-gel microcolumn and collected in vials containing

$3 \quad 23: 0$ as internal standard, with 1\% butylated hydroxytoluene (BHT) as the

4 antioxidant (Marty et al., 1992). Fatty acids were transesterified with boron-

5 trifluoride methanol ( $\mathrm{BF}_{3} 14 \%$ methanol, Supelco), and purified using a high-

6 precision liquid chromatogram (HPLC, Merck) as described by Marty et al. (1992).

$7 \quad$ Purified fatty acid methyl esters were analyzed in a Chrompak 9001 gas

8 chromatograph (GC) equipped with DB-WAX capillary column $(25 \mathrm{~m} \times 0.32 \mathrm{~mm}$,

$9 \quad 0.2-\mu m$ film thickness) flame ionization detector with hydrogen as the carrier gas and

10 a temperature gradient from 150 to $250^{\circ} \mathrm{C}$ at $3^{\circ} \mathrm{C} \mathrm{min}^{-1}$. Fatty acids were identified

11 by comparing their retention times with those of standards run in the polar DBWAX

12 column and in a non-polar CP8 capillary column $(50 \mathrm{~m} \times 0.25 \mathrm{~mm}, 0.2-\mu \mathrm{m}$ film

13 thickness) with the concentration of each fatty acid corrected by correlation with the

14 response of the corresponding standard. The concentration of each fatty acid was

15 corrected in relation to its molecular weight, and fatty acids are reported in $\mu \mathrm{mol} / \mathrm{g}$

16 wet weight.

17 Only fatty acids, consisting on average of more than $1 \%$ of total fatty acids, were reported and considered for statistical analysis. The concentration of 20:1n-x represents the sum of three fatty acids: 20:1n-11, 20:1n-9, and 20:1n-7. The polyunsaturation index (PUI) was calculated, as described by Napolitano and Ackman (1993), but molar concentrations were used instead of percentage of total fatty acids.

All data are reported as mean \pm standard error. One-way ANOVA, followed by Tukey tests for mean comparison (Statistica version 5.0) were used to assess significant differences between sampling months. Fatty acids from the neutral and polar fractions of each tissue were analyzed separately. 


\section{Results}

There were two general accumulation patterns in female gonad tissue of fatty acid

4 concentration in the neutral fraction (Table 1): significantly higher fatty acid

5 concentrations in June (18:0, 18:1n-7, 18:2n-6, 18:4n-3, 22:6n-3, DMA, NMID, MUFA,

6 and PUFA), or progressive increases that were traced from February (16:0, 16:1n-7, 18:1n-

7 9, 18:3n-3, 20:1n-x, and SAT) or April (18:3n-3, 22:4(n-9)13t and total fatty acids). Only

8 the concentration of 20:4n-6 showed an irregular pattern, with higher values in February

9 and June. In the polar lipid fraction of gonads, a steep increase in fatty acids

10 concentrations, similar to that observed in the neutral lipid fraction, was observed in June

11 for 16:0, 18:0, 18:1n-9, 18:2n-6, 18:3n-3, 18:4n-3, 20:5n-3, 22:4(n-9)13t, 22:6n-3, SAT,

12 PUFA, and total fatty acids. The 14:0, 18:1n-7, 20:1n-x, 22:4(n-9)13t, and MUFA

concentrations increased in February, decreased in April, and finally increased in June.

In the neutral fraction of the digestive gland, the concentrations of 16:0, 18:0, 18:2n-6, 18:3n-3, 18:4n-3, 22:6n-3, TMTD, SAT, MUFA, PUFA, and total fatty acids were higher in April and June than in December and February (Table 2). The concentrations of 14:0, 16:1n-7, 18:1n-7, and 20:5n-3 increased progressively from December to June, while 18:1n-9 and 20:4n-6 were highest in April. In the polar lipid fraction of the digestive gland, concentrations and proportions of 18:4n-3 and 20:5n-3 increased progressively during gametogenesis. Concentrations of DMA were higher in April and June, but TMTD was higher in February. No significant differences were observed for the concentration of other 22 fatty acids.

In the neutral lipid fraction of the muscle, concentrations of 18:0, 18:1n-7, 20:5n-3,

24 DMA, and total fatty acids were higher in April and June compared to December and 25 February (Table 3). The lowest concentrations of 16:0, 18:1-9, 18:3n-3, 20:1n-x, 20:4n-6, 22:6n-3, MUFA, PUFA, and SAT were observed in February. Some of these fatty acids 
1 reached by April similar levels than in December (16:0, 20:1, 18:1n-9, 18:3n-3), while

2 others (20:4n-6, 22:6n-3, SAT, MUFA and PUFA) were significantly higher in April

3 and/or June compared to December. In the polar lipid fraction of muscle tissue, the

4 concentration of 18:4n-3 increased progressively during gametogenesis. The other fatty

5 acids did not present significant variation except for 20:4n-6 and NMID, which had their

6 lowest values in June.

7 Concentrations of the neutral fraction from the mantle of 18:0, 18:1-7, 20:4n-6, 20:5n-

8 3, 22:4(n-9)13t, 22:6n-3, DMA, NMID, SAT, PUFA, and total fatty acids increased in

9 April and June, compared to December and February (Table 4). In the polar lipid fraction

10 from the mantle, concentrations of $14: 0,16: 0,18: 0,16: 1 n-7,18: 1 n-7,18: 4 n-3,20: 5 n-3$,

11 SAT, MUFA, and total fatty acids increased progressively as gametogenesis progressed.

12 Figure 1 depicts variation of PUI, calculated from the total concentration of fatty acids

13 in the neutral and polar fractions, in relation to gametogenesis. PUI increased significantly

14 during April and June in the digestive gland and in June in female gonads. In muscle, there

15 was an increase in April, but no significant differences were found in the mantle.

\section{Discussion}

18 The scallops used in this study were sampled for fatty acid analyses starting in

19 December of 1999, when they were one year old and at the end of their first maturation. A

20 summary of data indicating the gonad development during the four months were adapted

21 from Racotta et al. (2003) to discuss fatty acid accumulation in relation to gametogenesis

22 (Table 5). Oocyte diameter in December (first sampling) was $13 \mu \mathrm{m}$, and some scallops

23 had partially spawned. After reproductive quiescence in January 2000 (oocyte diameter $=8$

$24 \mu \mathrm{m}$ ), an increase in gametogenesis activity was observed in February (second sampling),

25 and oocyte diameter increased to $12 \mu \mathrm{m}$. A peak in sexual maturity was observed in April

26 (third sampling), when oocyte diameter reached $48 \mu \mathrm{m}$, and some scallops had already 
1 spawned. Thus, results for April include data for completely mature (67\%) and partially

2 spawned (27\%) scallops. When the last samples were taken for fatty acid analyses in June,

3 scallops that had spawned in April were maturing again (100\% mature scallops with

4 oocyte diameter of $36 \mu \mathrm{m}$ ), and we did not find spawned scallops. These results coincide

5 with those for a closely related species, the tropical scallop Nodipecten nodosus, in which

6 spawning occurred between late May and late July (Lodeiros et al., 1998).

$7 \quad$ Gametogenesis and oocyte growth during this study involved either a steep increase in

8 the concentration of most fatty acids in both lipid fraction (especially in neutral lipids) of

9 the gonad in June, or a progressive increase during the sampling period. A progressive

10 increase in triacylglycerol concentration was also observed for the same scallops during

11 this sampling period (Racotta et al., 2003). The concentrations of SAT in the neutral

12 fraction of gonad tissue increased from 2.5 to $12.6 \mu \mathrm{mol} / \mathrm{g}$, and of MUFA from 0.4 to 5.3

$13 \mu \mathrm{mol} / \mathrm{g}$. The concentrations of SAT and MUFA are particularly important in this fraction

14 (acylglycerides) because most organisms readily catabolize SAT and MUFA to generate energy (Sargent et al., 1999). The concentration of SAT in the polar fraction of gonad

16 tissue also increased (2.1 to $6.2 \mu \mathrm{mol} / \mathrm{g}$ ), but not to the same degree as the neutral fraction.

17 However, the concentration of MUFA in the polar fraction was lower in December and in

18 April. The decrease of MUFA in April could be a result of a partial spawning observed in

19 some scallops, a process that requires energy. However, if this was the case, we would

20 expect a steeper decline in the SAT and MUFA of the neutral fractions, as has been

21 described for post-spawned Placopecten magellanicus scallops (Napolitano and Ackman, 22 1992).

23 PUFA contents of gonads increased from 4 to $30 \mu \mathrm{mol} / \mathrm{g}$ in the neutral fraction and

24 from 7 to $20 \mu \mathrm{mol} / \mathrm{g}$ in the polar fraction. Fatty acid composition in gonads of pectinids has often been characterized as having a high degree of unsaturation (Besnard et al., 1989; 
1 Napolitano and Ackman, 1993; Soudant et al., 1996a; Heras et al., 1997). Soudant et al.

2 (1996a) found that PUFA content of the neutral lipid fraction in gonads of Pecten maximus

3 scallops was approximately 45\%, and the PUFA content of the neutral lipid fraction in

4 gonads of Placopecten magellanicus was 44\% during the summer (Napolitano and

5 Ackman, 1992). PUFA content in the lion-paw scallop was also high, approximately 60\%

6 in the neutral fraction and 70\% in the polar fraction. PUFA can be used as an energy

7 source, as precursors of prostaglandins, and as structural components of phospholipids

8 (Ackman and Kean-Howie, 1995). An accumulation of 20:5n-3 is suggested by an increase

9 in its proportion in both the neutral (from 13\% in December to 21\% in June) and polar

10 fractions (from $14 \%$ in December to $20 \%$ in June). In the polar fraction, this could be a

11 result of its role in membrane function, mediated by some phospholipids (Soudant et al.,

12 1996b). While mollusks can use 20:5n-3 as an energy source during embryogenesis, the

13 maximum content of 20:5n-3 is probably regulated because it can compete with eicosanoid

14 production from 20:4n-6 (Sargent et al., 1999). However, no accumulation of 22:6n-3 was

15 observed in the gonads during gametogenesis. The concentration of 22:6n-3 tends to

16 remain constant during larval development (Whyte et al., 1990; Whyte and Boutillier,

17 1991; Soudant et al., 1998), although its synthesis is limited in mollusks (Waldock and

18 Holland, 1984; Chu and Greaves, 1991; Ackman and Kean-Howie, 1995; Soudant et al.,

19 1996a). The 22:6n-3 is conserved and incorporated into cellular membranes where it

20 modulates several membrane functions (Di Constanzo et al., 1983; Rabinovich and Ripatti,

21 1991; Farkas et al., 2000; Wu et al., 2001; Turner and Hulbert, 2003), rather than used as

22 an energy source because it is a poor substrate for energy-generating fatty acid oxidation

23 than more saturated fatty acids (Ackman and Kean-Howie, 1995; Sargent et al., 1999).

24 The variation of 20:4n-6 is interesting because its levels were higher in February and

25 June in the neutral fraction of female gonads. Although the role of $20: 4 n-6$ as an energy-

26 yielding fatty acid is probably negligible because of the low concentration in most tissues, 
1 it has an important role in prostaglandin production and as a component of

2 phosphatidylinositol (Foegh and Ramwell, 1983; Oliw et al., 1983; Stanley-Samuelson,

3 1987; Burgoyne and Morgan, 1990; Deridovich and Reunova, 1993; Soudant et al., 1998).

4 The decreased concentration of 20:4n-6 in the neutral fraction in December and April

5 could be associated with spawning (Table 5) and its role in prostaglandin production,

6 which stimulates muscle contraction and egg release (Martinez et al., 1996, 2000).

7 One of our objectives was to determine the storage site of long-chained PUFA during

8 maturation. PUI of the digestive gland was significantly higher in April and June, whereas

9 in female gonad it was higher only in June (Fig. 1). In muscle, PUI was higher in April,

10 and no differences in PUI were found in the mantle. Thus, mantle provides little or no

11 PUFA to gonads during maturation, and the levels of PUFA in muscle, particularly those

12 from the neutral fraction, are negligible compared to those in digestive gland, in

13 accordance to these being lean tissues, as pointed out by Napolitano and Ackman (1992).

14 However, some specific fatty acids could be transferred from muscle to gonad during

15 periods of less food availability. A negative correlation was found between muscle and

16 gonad for 20:5n-3, but only in April $(r=-0.65 ; P<0.05)$, probably indicating a transport

17 of this fatty acid from muscle to gonad. In addition, a decrease in the proportion of 22:6n-3

18 in the polar fraction of muscle (from 32\% in December to $26 \%$ in June) could indicate a

19 selective mobilization of this fatty acid to gonads.

20 For the digestive gland, no correlations were found between female gonads for 22:6n-3,

21 but partial mobilization of this fatty acid from digestive gland is suggested by the decrease

22 in its proportion from December to February in the neutral (from 22\% to 18\%) and in the

23 polar fractions (from 31 to $27 \%$ ). However, this was observed only at the beginning of

24 gametogenesis and no further decrease was observed during the months of more advanced

25 gonad development. This indicates that the main supply of 22:6n-3 in gonad during

26 maturation probably came directly from diet, without previous accumulation in the 
1 digestive gland. The sampling site, Bahía Magdalena, is particularly rich in phytoplankton

2 (Nienhius and Guerrero-Caballero, 1985; Gárate-Lizárraga and Siqueiros-Beltrones, 1998)

3 and the concentration of nutrients, chlorophyll a, and particulate matter at the site during

4 the same sampling period is reported in a parallel work (Cervantes-Duarte et al., 2004).

There was a negative correlation for 20:4n-6 between gonads and digestive gland in

6 April $(\mathrm{r}=-0.77 ; P<0.05)$, when the levels of this fatty acid in the neutral fraction of

7 digestive gland were highest, and in June $(r=-0.61 ; P<0.05)$, but no other negative

8 correlations were found. Positive correlations were found between 20:4n-6 in gonads and

9 20:4n-6 in muscle and mantle during December, February, and April, and with digestive

10 gland in December, indicating a parallel accumulation during algae blooms.

11 The content of trimethyltridecanoic acid (TMTD) in the digestive gland was 8\% in the 12 polar fraction and $2 \%$ in the neutral fraction. TMTD is a metabolic product of degradation 13 of phytol, a fatty alcohol side chain of chlorophylls (Napolitano and Ackman, 1993), and is 14 found mostly in the triacylglycerols of the digestive gland of scallops (Napolitano and 15 Ackman, 1993; Heras et al., 1997). The reason we found TMTD in the polar fraction could 16 be the timing of the digestion process. The majority of chlorophylls are associated with 17 photosynthetic pigments and photo systems in the thylakoid membranes of algae (Ramus, 18 1981). If samples of scallops were taken during initial digestion of algae, it is possible that 19 TMTD still would be attached to thylakoid membranes and be separated into the polar 20 fraction. We did not eliminate digestive gland contents prior to extraction, so it is probable 21 that its fatty acid composition reflected that of algae on which the scallop specimens were 22 feeding. Sampling of scallops during more advanced digestion could result in separation of 23 TMTD into the neutral fraction.

24 Like other pectinids, $N$. subnodosus had low total levels of non-methylene-interrupted 25 fatty acids (NMID) (Ackman and Hooper, 1973; Dembitsky et al., 1992; Napolitano et al., 26 1992; Marty et al., 1999; Freites et al., 2002). NMID concentrations were less than 1\% in 
1 the neutral fractions, although higher than expected concentrations of NMID of 20 and 22

2 carbons were found in the polar fraction of all tissues (1-3\% of the total). In addition to

3 NMID, we also found 22:4(n-9)13t, which was reported recently in certain pectinids by

4 Marty et al. (1999). As with NMID, the highest concentrations of 22:4(n-9)13t were found

5 in mantle tissue and the lowest in muscle tissue. When comparing the levels of 22:4(n-

6 9)13t during gametogenesis, we found an increase of the compound in the gonads and the

7 neutral fraction of mantle tissue.

8

\section{5. Conclusion}

10 Little transfer of essential PUFA from other tissues (muscle and digestive gland) to

11 gonads occurs during gametogenesis in N. subnodosus at the culture site at Bahía

12 Magdalena. These results are in accord with the high food availability at this site, sufficient

13 to sustain the energy and essential fatty needs for gonad development.

\section{Acknowledgments}

We are grateful to Dr. Elisa Serviere for help with algae structure. We also

acknowledge the collaboration of Jose Luis Ramírez and Diana Carreño during sampling, and the CIBNOR editor for improving the English text. This research was supported by a grant from Sistema de Investigación del Mar de Cortés (SIMAC BCS7001) and funds from CIBNOR project PAC30.

\section{References}

23 Ackman, R.G., Hooper, S.N. 1973. Non-methylene-interrupted fatty acids in lipids of

24 shallow-water marine invertebrates: a comparison of two molluscs (Littorina littorea and Lunatia triseriata) with the sand shrimp (Crangon septemspinosus). Comp. 
1 Ackman, R.G., Kean-Howie, J. 1995. Fatty acids in aquaculture: are w3 fatty acids always

2 important? In: Lim, C., Sessa, D.J. (Eds.), Nutrition and Utilization Technology in

3 Aquaculture., AOCA Press, Champaign, IL, pp. 82-104.

4 Arellano-Martínez, M., Racotta, I.S., Ceballos-Vázquez, B.P., Elorduy-Garay, J.F. 2004.

5 Biochemical composition, reproductive activity, and food availability of the lion's paw

6 scallop Nodipecten subnodosus in the laguna Ojo de Liebre. Baja California Sur,

$7 \quad$ Mexico. J. Shellfish Res. 23, 15-23.

8 Barber, B.J., Blake, N.J. 1981. Energy storage and utilization in relation to gametogenesis

$9 \quad$ in Argopecten irradians concentricus (Say). J. Exp. Mar. Biol. Ecol. 52, 121-134.

10 Barber, B.J., Blake, N.J. 1985. Substrate catabolism related to reproduction in the bay

11 scallop Argopecten irradians concentricus, as determined by $\mathrm{O} / \mathrm{N}$ and RQ

12 physiological indexes. Mar. Biol. 87, 13-18.

13 Barrios-Ruiz, D., Chávez-Villalba, J., Cáceres-Martínez, C. 2003. Growth of Nodipecten

14 subnodosus (Bivalvia: Pectinidae) in La Paz bay, Mexico. Aquacult. Res. 34, 633-639.

15 Beninger, P.G., Lucas, A. 1984. Seasonal variations in condition, reproductive activity, and

16 gross biochemical composition of two species of adult clam reared in a common

17 habitat: Tapes decussatus L. (Jeffreys) and Tapes philippinarum (Adams \& Reeve). J.

18 Exp. Mar. Biol. 79, 19-37.

19 Beninger, P.G., Stephan, G. 1985 Seasonal variations in the fatty acids of the

20 triacylglycerols and phospholipids of two populations of adult clam (Tapes decussatus

21 L. and T. philippinarum) reared in a common habitat. Comp. Biochem. Physiol. 81B,

$22 \quad 591-601$

23 Besnard, J.Y., Lubet, P., Nouvelot, A. 1989. Seasonal variations of the fatty acid content of

24 the neutral lipids and phospholipids in the female gonad of Pecten maximus L. Comp.

25 Biochem. Physiol. 93B, 21-26. 
1 Bligh, E.G., Dyer, W.J. 1959 A rapid method of total lipid extraction and purification. Can.

$2 \quad$ J. Biochem. Physiol. 37, 911-917.

3 Burgoyne, R.D., Morgan, A. 1990. The control of arachidonic levels. TIBS 15, 365-366.

4 Caers, M., Coutteau, P., Sorgeloos, P., Gajardo, G. 2003. Impact of algal diets and

5 emulsions on the fatty acid composition and content of selected tissues of adult

6 broodstock of the Chilean scallop Argopecten purpuratus (Lamarck, 1819).

$7 \quad$ Aquaculture 217, 437-452.

8 Cervantes-Duarte, R., González-Armas, R., Zaytesev, O. 2004 Annual cycle of chlorophyll

$9 \quad$ and nutrients in a coastal lagoon. Aquatic Living Res. (submitted)

10 Chu, F.L.E., Greaves, J. 1991 Metabolism of palmitic, linoleic and linolenic acids in adult 11 oysters, Crassostrea virginica. Mar. Biol. 110, 229-236.

12 Claere-Boudt, M.R., Himmelman. J.H. 1996 Recruitment, growth and production of giant 13 scallops (Placopecten magellanicus) along an environmental gradient in Baie des 14 Chaleurs, Eastern Canada. Mar. Biol. 124, 661-670.

15 Dembitsky, V.M., Kashin, A.G., Stefanov, K. 1992 Comparative investigation of 16 phospholipids and fatty acids of freshwater molluscs from the Volga river basin. Comp. 17 Biochem. Physiol. 102B, 193-198.

18 Deridovich, I.I., Reunova, O.V. 1993 Prostaglandins - Reproduction control in bivalve 19 mollusks. Comp. Biochem. Physiol. 104A, 23-27.

20 Di Costanzo, G., Duportail, G., Florentz, A., Leray, C. 1983. The brush border membrane 21 of trout intestine; influence of its lipid composition on ion permeability, enzyme 22 activity and membrane fluidity. Mol. Physiol. 4, 279-290.

23 Epp, J., Bricelj, V.M., Malouf, R.E. 1988. Seasonal partitioning and utilization of energy 24 reserves in two age classes of the Bay scallop Argopecten irradians irradians (L.). J. 25 Exp. Mar. Biol. Ecol. 121, 113-136. 
1 Farkas, T., Kitajka, K., Fodor, E., Csengeri, I., Lahdes, E., Yeo, Y.K., Krasznai, Z., Halver,

2 J.E. 2000. Docosahexaenoic acid-containing phospholipid molecular species in brains

3 of vertebrates. PNAS 97, 6362-6366.

4 Félix-Pico, E., Villalejo-Fuerte, M., Tripp-Quezada, A., Holguin-Quiñones, O. 1999.

5 Growth and survival of Lyropecten subnodosus (Sowerby, 1835) in suspended culture

6 at the National Marine Park of Bahía de Loreta, B.C.S., Mexico. 12th International

$7 \quad$ Pectinid Workshop, Bergen, Norway. pp. 39-40.

8 Foegh, M.L., Ramwell, P.W. 1983 Physiological implications of products in the

9 arachidonic acid cascade. In: Granström, P.A., (Ed.), Prostaglandins and Related

10 Substances. Elsevier Science Publishers, B.V. pp. 13-19.

11 Freites, L., Labarta, U., Fernandez-Reiriz, M.J. 2002 Evolution of fatty acid profiles of

12 subtidal and rocky shore mussel seed (Mytilus galloprovincialis, Lmk.). Influence of

13 environmental parameters. J. Exp. Mar. Biol. Ecol. 268, 185-204.

14 Garcia-Dominguez, F., Castro-Moroyoqui, P., Felix-Pico, E. 1992. Spat settlement and

15 early growth of Lyropecten subnudosus (Sowerby, 1835) in Laguna Ojo de Liebre,

$16 \quad$ B.C.S., Mexico, 1989-1990. J. Shellfish Res. 11, 195.

17 Gárate-Lizarraga, I., Siqueiros-Beltrones, D.A. 1998 Time variation in phytoplankton

18 assemblages in a subtropical lagoon system after the 1982-1983 “El Niño” event (1984-1986). Pacific Sc. 52, 79-97.

Heras, H., Gomez, C., Napolitano, G.E. 1997 Anatomical distribution of lipids and fatty acids in Placopecten magellanicus and Argopecten irradians from eastern Canada, and Chlamys tehuelcha from the Patagonian shelf (Argentina), 11th International. Pectinid Workshop, La Paz, B.C.S., México. pp. 76-78.

Lodeiros, C.J., Rengel, J.J., Freites, L., Morales, F., Himmelman, J.H. 1998 Growth and survival of the tropical scallop Lyropecten (Nodipecten) nodosus maintained in suspended culture at three depths. Aquaculture 165, 41-50. 
1 Luna-González, A., Cáceres, C., Zúñiga-Pacheco, C., López-López, S., Ceballos-Vázquez,

2 B.P. 2000. Reproductive cycle of Argopecten ventricosus (Soerby 1842) (Bivalvia:

3 Pectinidae) in the rada del Puerto de Pichilingue, B.C.S., and its relation to

4 temperature, salinity and food. J. Shellfish Res. 19, 107-112.

5 Martínez, G., Mettifogo, L. 1998 Mobilization of energy from adductor muscle for

6 gametogenesis of the scallop, Argopecten purpuratus Lamarck. J. Shellfish Res. 17, $7 \quad 113-116$

8 Martínez, G., Garrote, C., Mettifogo, L., Pérez, H., Uribe, E. 1996. Monoamines and 9 prostaglandin E2 as inducers of the spawning of the scallop, .Argopecten purpuratus $10 \quad$ Lamarck. J. Shellfish Res. 15, 245-249.

11 Martínez, G., Mettifogo, L., Lenoir, R., Olivares, A. 2000 Prostaglandins and reproduction 12 of the scallop Argopecten purpuratus: II. Relationship with gamete release. J. Exp. 13 Zool. 287, 86-91.

14 Marty, Y., Delauney, F., Moal, J., Samain, J.F. 1992 Changes in the fatty acid composition 15 of Pecten maximus (L.) during larval development. J. Exp. Mar. Biol. Ecol. 163, 22116234.

17 Marty, Y., Soudant, P., Perrote, S., Moal, J., Dussauze, J., Samain, J.F. 1999. Identification 18 and occurence of a novel cis-4,7,10,trans-13-docosatetraenoic fatty acid in the scallop Pecten maximus (L.). J. Chromatography 839, 119-127.

Mathieu, M., Lubet, P. 1993. Storage tissue metabolism and reproduction in marine bivalves - a brief review. Invert. Reprod. Develop. 23, 123-129.

22 Morales-Hernandez, R., Caceres-Martínez, C. 1996. Pesqueria de almeja mano de leon Lyropecten subnodosus. In: Casas-valdez, M., Ponce-Diaz, G. (Eds.), Estudio del Potencial Pesquero de Baja California Sur, La Paz (Mexico), pp. 87-100. 
1 Napolitano, G.E., Ackman, R.G. 1992 Anatomical distributions and temporal variations of

2 lipid classes in sea scallops Placopecten magellanicus (Gmelin) from Georges Bank

3 (Nova-Scotia). Comp. Biochem. Physiol. 103B, 645-650.

4 Napolitano, G.E., Ackman, R.G. 1993. Fatty acid dynamics in sea scallops Placopecten

5 magellanicus (Gmelin, 1791) from Georges Bank, Nova Scotia. J. Shellfish Res. 12,

$6 \quad 267-277$.

7 Napolitano, G.E., MacDonald, B.A., Thompson, R.J., Ackman, R.G. 1992. Lipid

8 composition of eggs and adductor muscle in giant scallops (Placopecten magellanicus)

$9 \quad$ from different habitats. Mar. Biol. 113, 71-76.

10 Nienhius, G.H., Guerrero-Caballero, R. 1985. A quantitative analysis of annual

11 phytoplankton cycle of the Magdalena lagoon complex (Mexico). J. Plank. Res. 7, 427-

12441.

13 Oliw, E., Granström, E., Änggard, E. 1983. The prostaglandins and essential fatty acids.

14 In: Granström, P.A., (Ed.), Prostaglandins and Related Substances. Elsevier Science

15 Publishers, B.V. pp. 1-44.

16 Pazos, A.J., Román, G., Acosta, C.P., Abad, M., Sánchez, J.L. 1996. Influence of the

17 gametogenic cycle on the biochemical composition of the ovary of the great scallop.

18 Aquacult. Int. 4, 201-213.

19 Pazos, A.J., Roman, G., Acosta, C.P., Abad, M., Sanchez, J.L. 1997. Seasonal changes in

20 condition and biochemical composition of the scallop Pecten maximus L. from

21 suspended culture in the Ria de Arousa (Galicia, N.W. Spain) in relation to

22 environmental conditions. J. Exp. Mar. Biol. Ecol. 211, 169-193.

23 Pernet, F., Tremblay, R., Bourget, E. 2003. Biochemical indicator of sea scallop

24 (Placopecten magellanicus) quality based on lipid class composition. Part I:

25 Broodstock conditioning and young larval performance. J. Shellfish Res. 22, 365-375. 
1 Rabinovich, A.L, Ripatti, P.O., 1991. On the conformational, physical properties and

2 functions of polyunsaturated acyl chains. Biochim. Biophys. Acta 1085, 53-62.

3 Racotta, I.S., Ramirez, J.L., Ibarra, A.M., Rodriguez-Jaramillo, M.C., Carreño, D.,

4 Palacios, E. 2003. Growth and gametogenesis in the lion-paw scallop Nodipecten

5 (Lyropecten) subnodosus. Aquaculture 217, 335-349.

6 Ramus, J. 1981. The capture and transduction of light energy. 458-492. In:

7 Lobban, C.S., Wynne, M.J. (Eds.), The Biology of Seaweeds. University of

8 California Press. Berkeley and Los Angeles.

9 Reinecke-Reyes, M.A. 1996. Madurez y desove de la almeja Mano de León Lyropecten

10 subnodosus Sowerby, 1835 (Bivalvia:Pectinidae) en laguna Ojo de Liebre, B.C.S.

11 México. Boletín Pesquero, CRIP, La Paz 3, 17-20.

12 Roman, G., Campos, M.J., Acosta, C.P. 1996. Relationships among environment, 13 spawning and settlement of Queen scallop in the Ría de Arosa (Galicia, NW Spain).

14 Aquacult. Int. 4, 225-236.

15 Ruiz-Verdugo, C.A., Racotta, I.S., Ibarra, A.M. 2001. Comparative biochemical

16 composition in gonad and adductor muscle of triploid and diploid catarina scallop

17 (Argopecten ventricosus Sowerby II, 1842). J. Exp. Mar. Biol. Ecol. 259, 155-170.

18 Sargent, J.R., Mc Evoy, L.A., Estevez, A., Bell, J.G., Bell, M.V., Henderson, R.J., Tocher,

19 D.R. 1999. Lipid nutrition of marine fish during early development: current status and

20 future directions. Aquaculture 179, 217-229.

21 Sokal, R.R., Rohlf, F.J. 1981. Biometry: The principles and practice of statistics in

22 biological research. W.H. Freeman and Company, New York.

23 Soudant, P., Marty, Y., Moal, J., Robert, R., Quéré, C., Le Coz, J.R., Samain, J.F. 1996a.

24 Effect of food fatty acid and sterol quality on Pecten maximus gonad composition and

25 reproduction process. Aquaculture 143, 361-378. 
1 Soudant, P., Moal, J., Marty, Y., Samain, J.F. 1996b. Impact of the quality of dietary fatty

2 acids on metabolism and the composition of polar lipid classes in female gonads of

3 Pecten maximus (L.). J. Exp. Mar. Biol. Ecol. 205, 149-163.

4 Soudant, P., Marty, Y., Moal, J., Masski, H., Samain, J.F. 1998. Fatty acid composition of

5 polar lipid classes during larval development of scallop Pecten maximus (L.). Comp.

$6 \quad$ Biochem. Physiol. 121A, 279-288.

7 Stanley-Samuelson, D.W. 1987. Physiological roles of prostaglandins and other

$8 \quad$ eicosanoids in invertebrates. Biol. Bull. 173, 92-109.

9 Thompson, R.J. 1977. Blood chemistry, biochemical composition, and the annual

10 reproductive cycle in the giant scallop, Placopecten magellanicus, from Southeast

11 Newfoundland. J. Fish. Res. Bd. Canada 34, 2104-2116.

12 Turner, N., Else, P.L., Hulbert, A.J. 2003. Docosahexaenoic acid (DHA) content of

13 membranes determines molecular activity of the sodium pump: Implications for disease

14 states and metabolism. Naturwissenschaften 90, 521-523.

15 Vasallo, M.T. 1973. Lipid storage and transfer in the scallop Chlamys hericia Gould.

16 Comp. Biochem. Physiol. 44A, 1169-1175.

17 Waldock, M.J., Holland, D.L. 1984. Fatty acid metabolism in young oyster, Crassostrea 18 gigas: polyunsaturated fatty acids. Lipids 19, 332-336.

Whyte, J.N.C., Bourne, N., Ginther, N.G. 1990. Biochemical and energy changes during embryogenesis in the rock scallop Crassadoma gigantea. Mar. Biol. 106, 239-244.

21 Whyte, J.N.C., Boutillier, J.A. 1991. Concentrations of inorganic elements and fatty acids 22 in geographic populations of the spot prawn Pandalus platyceros. Can. J. Fish. Aquat. 23 Sci. $48,382-390$.

24 Wu, B.J., Else, P.L., Storlien, L.H., Hulbert, A.J. 2001. Molecular activity of Na+/K+25 ATPase from different sources is related to the packing of membrane lipids. J. Exp. 26 Biol. 204, 4271-4280. 


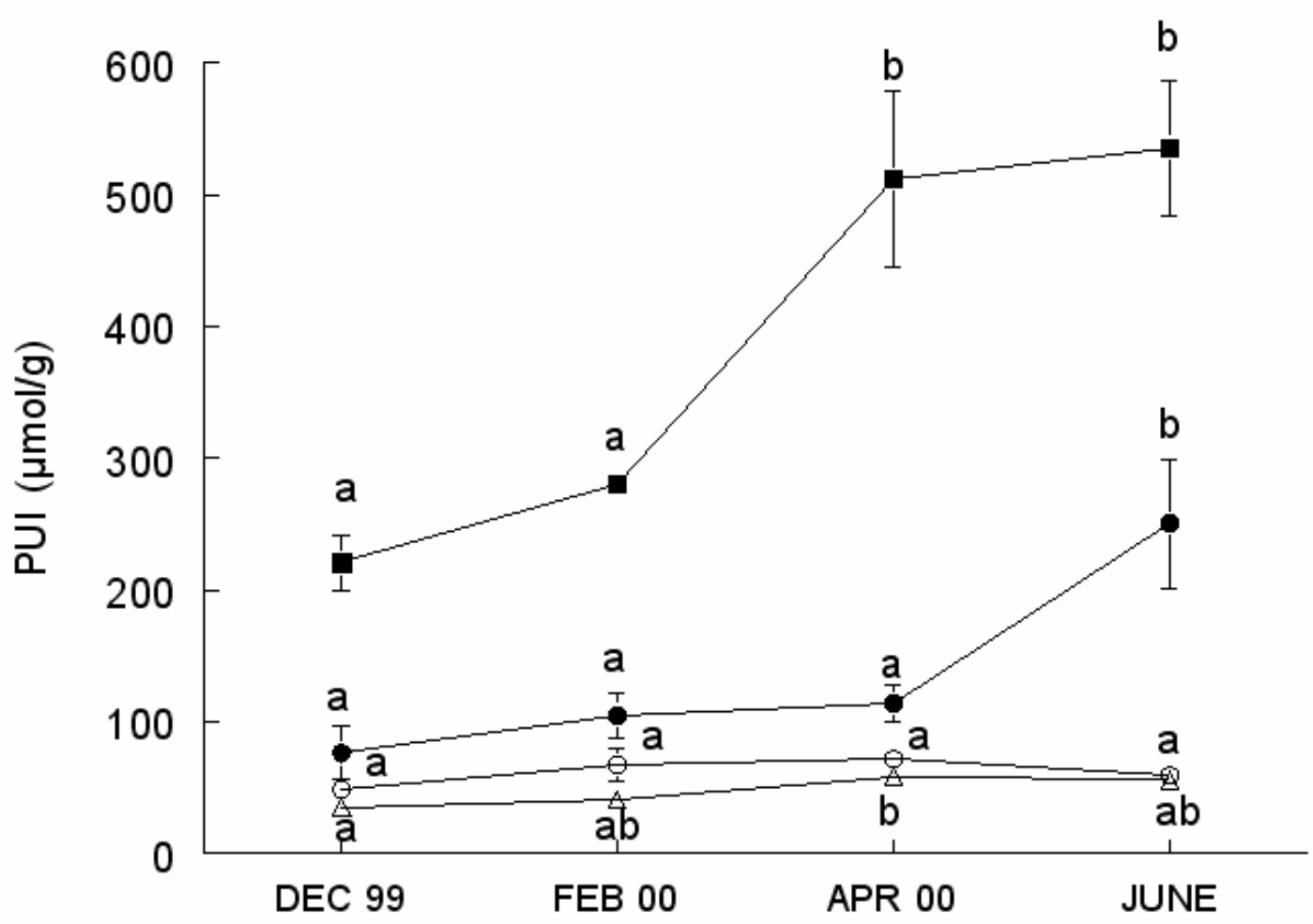

1

2 Fig.1. Variation in PUI $(\mu \mathrm{mol} / \mathrm{g}, \mathrm{w} / \mathrm{w})$ in relation to gametogenesis of Nodipecten

3 subnodosus, where female gonad = black circles; digestive gland = black squares; muscle

4 = white triangles; mantle $=$ white circles. Unifactorial ANOVA followed by Tukey post-

5 hoc analyses were applied to assess differences among means within the same tissue. $\mathrm{n}=5$

6 scallops for each sampling. Means sharing the same superscript were not significantly

7 different $(P<0.05)$. 
Table 1. Gonad fatty acid concentrations ( $\mu \mathrm{mol} / \mathrm{g}$, w/w) in neutral and polar fractions of Nodipecten subnodosus scallops sampled from December 1999 to June 2000. Unifactorial ANOVA followed by Tukey post-hoc analyses were applied to assess differences among means.

Means sharing different superscript in a row were significantly different $(P<0.05)$. Neutral and polar fractions were analyzed separately $(\mathrm{n}=$ 5).

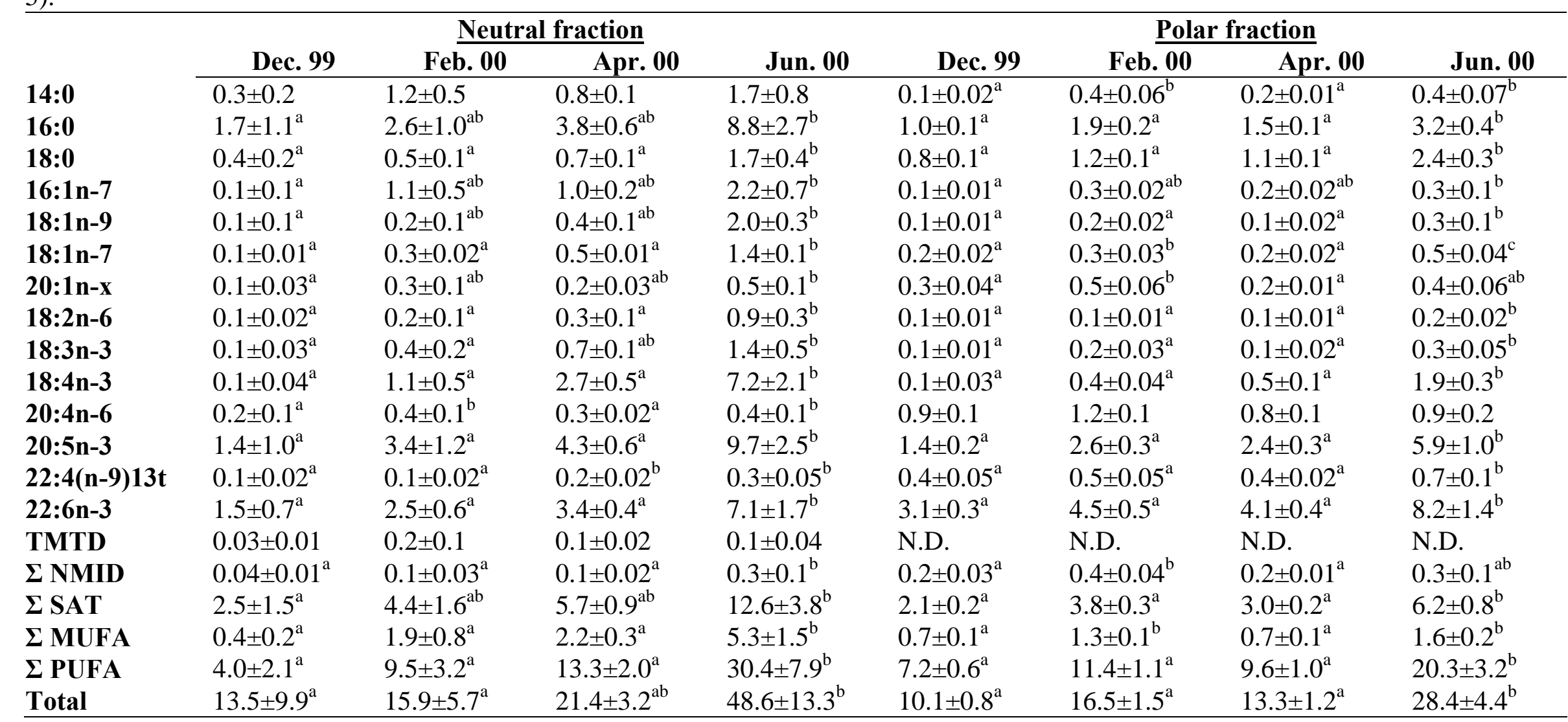

20:1n-x = 20:1n-11, 20:1n-9, 20:1n-7; TMTD = Trimethyltridecanoic acid; NMID = Non-methylene-interrupted fatty acids; SAT = Saturated; MUFA = Monounsaturated fatty acids; PUFA = Polyunsaturated fatty acids; N.D. = Not detected. 
Table 2. Digestive gland concentrations ( $\mu \mathrm{mol} / \mathrm{g}, \mathrm{w} / \mathrm{w}$ ) and percentage (in parenthesis) in neutral and polar fractions of Nodipecten subnodosus scallops sampled from December 1999 to June 2000. Unifactorial ANOVA followed by Tukey post-hoc analyses were applied to assess differences among means. Means sharing different superscript in a row were significantly different $(P<0.05)$. Neutral and polar fractions were analyzed separately $(\mathrm{n}=5)$.

\begin{tabular}{|c|c|c|c|c|c|c|c|c|}
\hline & \multicolumn{4}{|c|}{ Neutral fraction } & \multicolumn{4}{|c|}{ Polar fraction } \\
\hline & Dec. 99 & Feb. 00 & Apr. 00 & Jun. 00 & Dec. 99 & Feb. 00 & Apr. 00 & Jun. 00 \\
\hline 14:0 & $4.1 \pm 0.3^{\mathrm{a}}$ & $5.7 \pm 0.4^{\mathrm{a}}$ & $7.3 \pm 0.7^{\mathrm{ab}}$ & $7.8 \pm 0.7^{b}$ & $0.4 \pm 0.1$ & $0.9 \pm 0.2$ & $0.8 \pm 0.2$ & $1.1 \pm 0.4$ \\
\hline 16:0 & $14.0 \pm 1.1^{\mathrm{a}}$ & $16.2 \pm 1.0^{\mathrm{a}}$ & $27.1 \pm 3.5^{b}$ & $26.2 \pm 2.7^{b}$ & $2.4 \pm 0.4$ & $3.7 \pm 0.7$ & $4.1 \pm 0.8$ & $4.8 \pm 1.5$ \\
\hline 18:0 & $2.0 \pm 0.2^{\mathrm{a}}$ & $2.1 \pm 0.2^{\mathrm{a}}$ & $3.5 \pm 0.6^{\mathrm{b}}$ & $3.5 \pm 0.4^{\mathrm{b}}$ & $1.4 \pm 0.2$ & $1.9 \pm 0.13$ & $2.0 \pm 0.2$ & $1.8 \pm 0.3$ \\
\hline $16: 1 n-7$ & $5.0 \pm 0.50^{\mathrm{a}}$ & $6.8 \pm 0.4^{\mathrm{ab}}$ & $9.2 \pm 0.8^{\mathrm{bc}}$ & $10.5 \pm 1.1^{\mathrm{c}}$ & $0.5 \pm 0.1$ & $0.9 \pm 0.3$ & $1.0 \pm 0.2$ & $1.3 \pm 0.5$ \\
\hline 18:1n-9 & $2.3 \pm 0.1^{\mathrm{a}}$ & $2.4 \pm 0.2^{\mathrm{a}}$ & $4.4 \pm 0.6^{\mathrm{b}}$ & $3.4 \pm 0.4^{\mathrm{a}}$ & $0.4 \pm 0.1$ & $0.4 \pm 0.1$ & $0.5 \pm 0.1$ & $0.6 \pm 0.2$ \\
\hline $18: 1 n-7$ & $1.8 \pm 0.2^{\mathrm{a}}$ & $2.1 \pm 0.1^{\mathrm{ab}}$ & $3.3 \pm 0.5^{b}$ & $3.3 \pm 0.4^{\mathrm{b}}$ & $0.3 \pm 0.1$ & $0.5 \pm 0.1$ & $0.6 \pm 0.1$ & $0.7 \pm 0.2$ \\
\hline 20:1n-x & $0.5 \pm 0.1$ & $0.5 \pm 0.1$ & $0.8 \pm 0.1$ & $0.7 \pm 0.1$ & $0.3 \pm 0.03$ & $0.3 \pm 0.04$ & $0.4 \pm 0.03$ & $0.4 \pm 0.1$ \\
\hline $18: 2 n-6$ & $1.8 \pm 0.1^{\mathrm{a}}$ & $1.9 \pm 0.1^{\mathrm{a}}$ & $4.0 \pm 0.6^{\mathrm{b}}$ & $3.3 \pm 0.3^{b}$ & $0.2 \pm 0.1$ & $0.3 \pm 0.1$ & $0.4 \pm 0.1$ & $0.5 \pm 0.2$ \\
\hline $18: 3 n-3$ & $2.3 \pm 0.2^{\mathrm{a}}$ & $2.5 \pm 0.1^{\mathrm{a}}$ & $6.5 \pm 1.0^{\mathrm{b}}$ & $5.1 \pm 0.5^{\mathrm{b}}$ & $0.3 \pm 0.1$ & $0.6 \pm 0.1$ & $0.6 \pm 0.2$ & $0.8 \pm 0.2$ \\
\hline $18: 4 n-3$ & $4.8 \pm 0.5^{\mathrm{a}}$ & $5.1 \pm 1.3^{\mathrm{a}}$ & $15.0 \pm 2.2^{b}$ & $16.6 \pm 1.2^{\mathrm{b}}$ & $0.6 \pm 0.2^{\mathrm{a}}$ & $1.3 \pm 0.2^{\mathrm{a}}$ & $1.7 \pm 0.4^{\mathrm{ab}}$ & $3.1 \pm 0.7^{\mathrm{b}}$ \\
\hline $20: 4 n-6$ & $0.7 \pm 0.1^{\mathrm{a}}$ & $1.1 \pm 0.1^{\mathrm{b}}$ & $1.6 \pm 0.2^{\mathrm{C}}$ & $1.2 \pm 0.2^{\mathrm{b}}$ & $1.2 \pm 0.02$ & $1.1 \pm 0.02$ & $1.2 \pm 0.1$ & $0.7 \pm 0.1$ \\
\hline $20: 5 n-3$ & $11.6 \pm 1.4^{\mathrm{a}}$ & $18.1 \pm 0.9^{b}$ & $33.8 \pm 4.5^{b}$ & $36.4 \pm 2.7^{b}$ & $3.9 \pm 1.0^{\mathrm{a}}$ & $6.1 \pm 0.5^{\mathrm{ab}}$ & $7.8 \pm 0.8^{\mathrm{ab}}$ & $8.2 \pm 1.9^{b}$ \\
\hline $22: 4(n-9) 13 t$ & $0.2 \pm 0.03$ & $0.2 \pm 0.02$ & $0.3 \pm 0.1$ & $0.2 \pm 0.04$ & $0.6 \pm 0.1$ & $0.6 \pm 0.02$ & $0.7 \pm 0.1$ & $0.5 \pm 0.1$ \\
\hline $22: 6 n-3$ & $6.8 \pm 0.6^{\mathrm{a}}$ & $5.6 \pm 0.4^{\mathrm{a}}$ & $13.2 \pm 2.2^{b}$ & $12.6 \pm 1.1^{\mathrm{b}}$ & $4.5 \pm 0.8$ & $4.7 \pm 0.3$ & $6.0 \pm 0.4$ & $6.0 \pm 0.9$ \\
\hline TMTD & $1.05 \pm 0.1^{\mathrm{a}}$ & $1.2 \pm 0.1^{\mathrm{a}}$ & $2.0 \pm 0.2^{\mathrm{b}}$ & $2.1 \pm 0.2^{\mathrm{b}}$ & $1.4 \pm 0.3^{\mathrm{a}}$ & $2.8 \pm 0.2^{\mathrm{b}}$ & $1.4 \pm 0.2^{\mathrm{a}}$ & $1.7 \pm 0.2^{\mathrm{a}}$ \\
\hline$\Sigma$ NMID & $0.2 \pm 0.04$ & $0.1 \pm 0.02$ & $0.1 \pm 0.07$ & $0.1 \pm 0.02$ & $0.2 \pm 0.04$ & $0.3 \pm 0.01$ & $0.3 \pm 0.02$ & $0.3 \pm 0.1$ \\
\hline$\Sigma$ SAT & $21.0 \pm 1.52^{\mathrm{a}}$ & $25.0 \pm 1.5^{\mathrm{a}}$ & $39.4 \pm 4.9^{b}$ & $38.9 \pm 3.9^{\mathrm{b}}$ & $4.5 \pm 0.8$ & $6.9 \pm 1.1$ & $7.3 \pm 1.1$ & $8.1 \pm 2.3$ \\
\hline$\Sigma$ MUFA & $9.9 \pm 0.8^{\mathrm{a}}$ & $12.0 \pm 0.6^{\mathrm{a}}$ & $18.3 \pm 2.1^{b}$ & $18.4 \pm 1.97^{\mathrm{b}}$ & $1.5 \pm 0.3$ & $2.3 \pm 0.5$ & $2.5 \pm 0.51$ & $3.2 \pm 1.0$ \\
\hline$\Sigma$ PUFA & $33.3 \pm 3.0^{\mathrm{a}}$ & $41.2 \pm 1.6^{\mathrm{a}}$ & $86.7 \pm 12.7^{\mathrm{b}}$ & $90.1 \pm 7.3^{\mathrm{b}}$ & $13.0 \pm 2.6$ & $16.6 \pm 1.3$ & $20.7 \pm 2.0$ & $22.4 \pm 4.7$ \\
\hline Total & $65.7 \pm 1.2^{\mathrm{a}}$ & $79.7 \pm 0.7^{\mathrm{a}}$ & $148 \pm 4.4^{\mathrm{b}}$ & $151 \pm 3.0^{\mathrm{b}}$ & $20.5 \pm 0.9$ & $28.7 \pm 0.6$ & $32.1 \pm 0.8$ & $35.6 \pm 1.8$ \\
\hline
\end{tabular}

See table 1 for abbreviations. 
Table 3. Muscle acid concentrations ( $\mu \mathrm{mol} / \mathrm{g}, \mathrm{w} / \mathrm{w}$ ) and percentage (in parenthesis) in neutral and polar fractions of Nodipecten subnodosus scallops sampled from December 1999 to June 2000. Unifactorial ANOVA followed by Tukey post-hoc analyses were applied to assess differences among means. Means sharing different superscript in a row were significantly different $(P<0.05)$. Neutral and polar fractions were analyzed separately $(\mathrm{n}=5)$.

14:0

16:0

18:0

16:1n-7

18:1n-9

18:1n-7

20:1n-x

18:2n-6

18:3n-3

18:4n-3

20:4n-6

20:5n-3

22:4(n-9)13t

22:6n-3

TMTD

$\Sigma$ NMID

$\Sigma$ SAT

$\Sigma$ MUFA

$\Sigma$ PUFA

Total

Neutral fraction

\section{Polar fraction}

\begin{tabular}{|c|c|c|c|c|c|c|c|}
\hline \multirow[b]{2}{*}{ Dec. 99} & & \multirow[b]{2}{*}{ Jun. 00} & \\
\hline & Feb. 00 & Apr. 00 & & Dec. 99 & Feb. 00 & Apr. 00 & Jun. 00 \\
\hline $0.05 \pm 0.01$ & $0.03 \pm 0.01$ & $0.04 \pm 0.01$ & $0.04 \pm 0.01$ & $0.1 \pm 0.01$ & $0.3 \pm 0.1$ & $0.3 \pm 0.02$ & $0.2 \pm 0.03$ \\
\hline $0.2 \pm 0.03^{\mathrm{ab}}$ & $0.1 \pm 0.01^{\mathrm{a}}$ & $0.3 \pm 0.04^{b}$ & $0.3 \pm 0.02^{b}$ & $1.7 \pm 0.23$ & $2.6 \pm 0.51$ & $2.7 \pm 0.21$ & $2.1 \pm 0.3$ \\
\hline $0.1 \pm 0.01^{\mathrm{a}}$ & $0.1 \pm 0.01^{\mathrm{a}}$ & $0.2 \pm 0.03^{b}$ & $0.2 \pm 0.03^{b}$ & $0.9 \pm 0.1$ & $1.1 \pm 0.2$ & $1.0 \pm 0.1$ & $0.8 \pm 0.1$ \\
\hline $0.06 \pm 0.01$ & $0.04 \pm 0.01$ & $0.05 \pm 0.01$ & $0.06 \pm 0.01$ & $0.1 \pm 0.02$ & $0.3 \pm 0.07$ & $0.2 \pm 0.02$ & $0.2 \pm 0.1$ \\
\hline $0.04 \pm 0.01^{\mathrm{ab}}$ & $0.03 \pm 0.01^{\mathrm{a}}$ & $0.05 \pm 0.01^{\mathrm{b}}$ & $0.06 \pm 0.01^{\mathrm{b}}$ & $0.2 \pm 0.01$ & $0.2 \pm 0.04$ & $0.2 \pm 0.02$ & $0.2 \pm 0.02$ \\
\hline $0.04 \pm 0.01^{\mathrm{a}}$ & $0.03 \pm 0.01^{\mathrm{a}}$ & $0.08 \pm 0.01^{b}$ & $0.10 \pm 0.01^{\mathrm{b}}$ & $0.3 \pm 0.04$ & $0.4 \pm 0.1$ & $0.5 \pm 0.04$ & $0.4 \pm 0.1$ \\
\hline $0.02 \pm 0.01^{\mathrm{ab}}$ & $0.01 \pm 0.01^{\mathrm{a}}$ & $0.06 \pm 0.01^{\mathrm{b}}$ & $0.07 \pm 0.01^{b}$ & $0.3 \pm 0.02$ & $0.4 \pm 0.1$ & $0.3 \pm 0.01$ & $0.3 \pm 0.02$ \\
\hline $0.02 \pm 0.004$ & $0.01 \pm 0.001$ & $0.02 \pm 0.003$ & $0.02 \pm 0.002$ & $0.1 \pm 0.01$ & $0.2 \pm 0.03$ & $0.2 \pm 0.01$ & $0.1 \pm 0.02$ \\
\hline $0.02 \pm 0.01^{\mathrm{ab}}$ & $0.01 \pm 0.01^{\mathrm{a}}$ & $0.03 \pm 0.01^{b}$ & $0.02 \pm 0.01^{\mathrm{ab}}$ & $0.1 \pm 0.01$ & $0.2 \pm 0.03$ & $0.2 \pm 0.01$ & $0.2 \pm 0.04$ \\
\hline $0.05 \pm 0.01$ & $0.03 \pm 0.01$ & $0.08 \pm 0.02$ & $0.08 \pm 0.02$ & $0.1 \pm 0.03^{\mathrm{a}}$ & $0.5 \pm 0.1^{\mathrm{ab}}$ & $0.6 \pm 0.04^{\mathrm{b}}$ & $0.7 \pm 0.2^{\mathrm{b}}$ \\
\hline $0.06 \pm 0.02^{\mathrm{a}}$ & $0.02 \pm 0.01^{\mathrm{a}}$ & $0.11 \pm 0.03^{b}$ & $0.13 \pm 0.02^{\mathrm{b}}$ & $0.6 \pm 0.01^{\mathrm{ab}}$ & $0.8 \pm 0.2^{\mathrm{a}}$ & $0.6 \pm 0.03^{\mathrm{ab}}$ & $0.4 \pm 0.03^{b}$ \\
\hline $0.2 \pm 0.04^{\mathrm{a}}$ & $0.1 \pm 0.01^{\mathrm{a}}$ & $0.5 \pm 0.1^{\mathrm{b}}$ & $0.6 \pm 0.1^{\mathrm{b}}$ & $2.0 \pm 0.4$ & $3.8 \pm 0.7$ & $4.2 \pm 0.3$ & $3.3 \pm 0.6$ \\
\hline $0.02 \pm 0.01$ & $0.01 \pm 0.001$ & $0.03 \pm 0.001$ & $0.04 \pm 0.02$ & $0.3 \pm 0.01$ & $0.3 \pm 0.04$ & $0.3 \pm 0.02$ & $0.2 \pm 0.03$ \\
\hline $0.4 \pm 0.1^{\mathrm{a}}$ & $0.2 \pm 0.1^{\mathrm{a}}$ & $0.8 \pm 0.1^{\mathrm{b}}$ & $0.8 \pm 0.1^{\mathrm{b}}$ & $3.9 \pm 0.4$ & $5.3 \pm 1.1$ & $4.7 \pm 0.3$ & $3.5 \pm 0.3$ \\
\hline $0.01 \pm 0.002$ & N.D. & $0.01 \pm 0.002$ & $0.01 \pm 0.002$ & N.D. & N.D. & $0.03 \pm 0.01$ & $0.03 \pm 0.01$ \\
\hline $0.01 \pm 0.01$ & $0.01 \pm 0.01$ & $0.01 \pm 0.01$ & $0.01 \pm 0.01$ & $0.09 \pm 0.01^{\mathrm{ab}}$ & $0.11 \pm 0.02^{\mathrm{a}}$ & $0.07 \pm 0.01^{\mathrm{ab}}$ & $0.05 \pm 0.01^{b}$ \\
\hline $0.4 \pm 0.1^{\mathrm{ab}}$ & $0.2 \pm 0.1^{\mathrm{a}}$ & $0.5 \pm 0.1^{\mathrm{bc}}$ & $0.6 \pm 0.1^{\mathrm{c}}$ & $3.0 \pm 0.3$ & $4.2 \pm 0.8$ & $4.2 \pm 0.3$ & $3.2 \pm 0.5$ \\
\hline $0.2 \pm 0.04^{\mathrm{ab}}$ & $0.1 \pm 0.01^{\mathrm{a}}$ & $0.3 \pm 0.04^{\mathrm{bc}}$ & $0.3 \pm 0.03^{c}$ & $0.9 \pm 0.1$ & $1.4 \pm 0.3$ & $1.28 \pm 0.1$ & $1.1 \pm 0.2$ \\
\hline $0.8 \pm 0.2^{\mathrm{ab}}$ & $0.4 \pm 0.1^{\mathrm{a}}$ & $1.7 \pm 0.3^{\mathrm{bc}}$ & $1.9 \pm 0.2^{\mathrm{C}}$ & $8.3 \pm 0.9$ & $12.4 \pm 2.5$ & $12.1 \pm 0.8$ & $9.5 \pm 1.3$ \\
\hline $1.4 \pm 0.3^{\mathrm{ab}}$ & $0.7 \pm 0.1^{\mathrm{a}}$ & $2.5 \pm 0.4^{\mathrm{b}}$ & $2.8 \pm 0.3^{b}$ & $12.3 \pm 1.3$ & $18.1 \pm 3.5$ & $17.6 \pm 1.2$ & $13.9 \pm 1.9$ \\
\hline
\end{tabular}

See table 1 for abbreviations. 
Table 4. Mantle acid concentrations ( $\mu \mathrm{mol} / \mathrm{g}, \mathrm{w} / \mathrm{w}$ ) and percentage (in parenthesis) in neutral and polar fractions of scallops sampled from December 1999 to June 2000. Unifactorial ANOVA followed by Tukey post-hoc analyses were applied to assess differences among means. Means sharing different superscript in a row were significantly different $(P<0.05)$. Neutral and polar fractions were analyzed separately $(\mathrm{n}=5)$.

\begin{tabular}{|c|c|c|c|c|c|c|c|c|}
\hline & \multicolumn{4}{|c|}{ Neutral fraction } & \multicolumn{4}{|c|}{ Polar fraction } \\
\hline & Dec. 99 & Feb. 00 & Apr. 00 & Jun. 00 & Dec. 99 & Feb. 00 & Apr. 00 & Jun. 00 \\
\hline 14:0 & $0.02 \pm 0.003$ & $0.03 \pm 0.01$ & $0.04 \pm 0.01$ & $0.04 \pm 0.01$ & $0.1 \pm 0.01^{\mathrm{a}}$ & $0.2 \pm 0.01^{b}$ & $0.2 \pm 0.02^{b}$ & $0.2 \pm 0.03^{b}$ \\
\hline 16:0 & $0.1 \pm 0.02$ & $0.2 \pm 0.03$ & $0.4 \pm 0.04$ & $0.3 \pm 0.04$ & $0.9 \pm 0.04^{\mathrm{a}}$ & $1.1 \pm 0.1^{\mathrm{ab}}$ & $1.5 \pm 0.2^{b}$ & $1.5 \pm 0.1^{\mathrm{b}}$ \\
\hline 18:0 & $0.1 \pm 0.01^{\mathrm{a}}$ & $0.1 \pm 0.01^{\mathrm{a}}$ & $0.3 \pm 0.03^{b}$ & $0.2 \pm 0.02^{b}$ & $0.7 \pm 0.03^{\mathrm{a}}$ & $0.9 \pm 0.1^{\mathrm{ab}}$ & $1.1 \pm 0.1^{\mathrm{b}}$ & $1.2 \pm 0.1^{\mathrm{b}}$ \\
\hline 16:1n-7 & $0.03 \pm 0.01$ & $0.04 \pm 0.01$ & $0.04 \pm 0.01$ & $0.04 \pm 0.01$ & $0.07 \pm 0.01^{\mathrm{a}}$ & $0.12 \pm 0.02^{\mathrm{ab}}$ & $0.11 \pm 0.01^{\mathrm{ab}}$ & $0.14 \pm 0.02^{b}$ \\
\hline 18:1n-9 & $0.03 \pm 0.01^{\mathrm{a}}$ & $0.03 \pm 0.01^{\mathrm{a}}$ & $0.06 \pm 0.01^{\mathrm{b}}$ & $0.04 \pm 0.01^{\mathrm{ab}}$ & $0.1 \pm 0.01$ & $0.2 \pm 0.02$ & $0.2 \pm 0.02$ & $0.2 \pm 0.02$ \\
\hline 18:1n-7 & $0.02 \pm 0.01^{\mathrm{a}}$ & $0.02 \pm 0.01^{\mathrm{a}}$ & $0.05 \pm 0.01^{\mathrm{b}}$ & $0.05 \pm 0.01^{\mathrm{b}}$ & $0.16 \pm 0.01^{\mathrm{a}}$ & $0.21 \pm 0.02^{\mathrm{ab}}$ & $0.28 \pm 0.03^{\mathrm{bc}}$ & $0.35 \pm 0.04^{\mathrm{c}}$ \\
\hline 20:1n-x & $0.02 \pm 0.01^{\mathrm{ab}}$ & $0.01 \pm 0.01^{\mathrm{a}}$ & $0.05 \pm 0.01^{\mathrm{b}}$ & $0.04 \pm 0.01^{\mathrm{ab}}$ & $0.2 \pm 0.01$ & $0.2 \pm 0.01$ & $0.2 \pm 0.01$ & $0.2 \pm 0.01$ \\
\hline $18: 2 n-6$ & $0.01 \pm 0.01^{\mathrm{a}}$ & $0.01 \pm 0.01^{\mathrm{ab}}$ & $0.02 \pm 0.01^{\mathrm{ab}}$ & $0.02 \pm 0.01^{\mathrm{b}}$ & $0.1 \pm 0.01$ & $0.1 \pm 0.01$ & $0.1 \pm 0.01$ & $0.1 \pm 0.02$ \\
\hline $18: 3 n-3$ & $0.01 \pm 0.001$ & $0.01 \pm 0.003$ & $0.03 \pm 0.01$ & $0.01 \pm 0.003$ & $0.03 \pm 0.002$ & $0.04 \pm 0.004$ & $0.04 \pm 0.01$ & $0.05 \pm 0.01$ \\
\hline $18: 4 n-3$ & $0.01 \pm 0.002^{\mathrm{a}}$ & $0.03 \pm 0.01^{\mathrm{ab}}$ & $0.04 \pm 0.01^{\mathrm{ab}}$ & $0.05 \pm 0.01^{\mathrm{b}}$ & $0.06 \pm 0.01^{\mathrm{a}}$ & $0.11 \pm 0.02^{\mathrm{a}}$ & $0.15 \pm 0.02^{\mathrm{ab}}$ & $0.29 \pm 0.06^{b}$ \\
\hline 20:4n-6 & $0.10 \pm 0.03^{\mathrm{a}}$ & $0.07 \pm 0.01^{\mathrm{a}}$ & $0.28 \pm 0.04^{\mathrm{b}}$ & $0.23 \pm 0.03^{b}$ & $0.8 \pm 0.1$ & $0.9 \pm 0.1$ & $0.9 \pm 0.1$ & $0.8 \pm 0.1$ \\
\hline $20: 5 n-3$ & $0.09 \pm 0.02^{\mathrm{a}}$ & $0.12 \pm 0.04^{\mathrm{a}}$ & $0.36 \pm 0.05^{b}$ & $0.32 \pm 0.04^{b}$ & $0.8 \pm 0.04^{\mathrm{a}}$ & $1.3 \pm 0.1^{\mathrm{ab}}$ & $1.8 \pm 0.2^{\mathrm{b}}$ & $1.8 \pm 0.3^{b}$ \\
\hline $22: 4(n-9) 13 t$ & $0.04 \pm 0.02^{\mathrm{a}}$ & $0.01 \pm 0.01^{\mathrm{a}}$ & $0.11 \pm 0.02^{b}$ & $0.10 \pm 0.02^{b}$ & $0.5 \pm 0.04$ & $0.6 \pm 0.1$ & $0.6 \pm 0.1$ & $0.6 \pm 0.1$ \\
\hline $22: 6 n-3$ & $0.3 \pm 0.2^{\mathrm{a}}$ & $0.2 \pm 0.1^{\mathrm{a}}$ & $1.2 \pm 0.1^{\mathrm{b}}$ & $0.9 \pm 0.1^{\mathrm{b}}$ & $2.7 \pm 0.2$ & $3.4 \pm 0.4$ & $4.1 \pm 0.5$ & $4.1 \pm 0.4$ \\
\hline TMTD & N.D. & N.D. & N.D. & N.D. & N.D. & N.D. & N.D. & N.D. \\
\hline$\Sigma$ NMID & $0.01 \pm 0.01^{\mathrm{a}}$ & $0.01 \pm 0.01^{\mathrm{a}}$ & $0.07 \pm 0.02^{\mathrm{b}}$ & $0.05 \pm 0.01^{\mathrm{b}}$ & $0.1 \pm 0.02$ & $0.2 \pm 0.03$ & $0.2 \pm 0.02$ & $0.2 \pm 0.03$ \\
\hline$\Sigma$ Saturated & $0.3 \pm 0.03^{\mathrm{a}}$ & $0.3 \pm 0.04^{\mathrm{a}}$ & $0.6 \pm 0.1^{\mathrm{b}}$ & $0.6 \pm 0.1^{\mathrm{b}}$ & $1.8 \pm 0.1^{\mathrm{a}}$ & $2.3 \pm 0.2^{\mathrm{ab}}$ & $3.0 \pm 0.3^{b}$ & $3.0 \pm 0.3^{b}$ \\
\hline$\Sigma$ MUFA & $0.10 \pm 0.02^{\mathrm{a}}$ & $0.11 \pm 0.02^{\mathrm{ab}}$ & $0.21 \pm 0.03^{b}$ & $0.19 \pm 0.02^{\mathrm{ab}}$ & $0.6 \pm 0.02^{\mathrm{a}}$ & $0.7 \pm 0.1^{\mathrm{ab}}$ & $0.8 \pm 0.1^{\mathrm{ab}}$ & $0.9 \pm 0.1^{\mathrm{b}}$ \\
\hline$\Sigma$ PUFA & $0.6 \pm 0.3^{\mathrm{a}}$ & $0.5 \pm 0.2^{\mathrm{a}}$ & $2.4 \pm 0.3^{\mathrm{b}}$ & $1.9 \pm 0.2^{\mathrm{b}}$ & $5.8 \pm 0.4$ & $7.4 \pm 0.9$ & $8.8 \pm 0.9$ & $8.9 \pm 1.0$ \\
\hline Total & $1.1 \pm 0.3^{\mathrm{a}}$ & $0.9 \pm 0.3^{\mathrm{a}}$ & $3.2 \pm 0.4^{\mathrm{b}}$ & $2.7 \pm 0.3^{\mathrm{b}}$ & $8.3 \pm 0.4^{\mathrm{a}}$ & $10.6 \pm 1.1^{\mathrm{ab}}$ & $12.8 \pm 1.3^{\mathrm{b}}$ & $13.1 \pm 1.4^{\mathrm{b}}$ \\
\hline
\end{tabular}

See table 1 for abbreviations. 
Table 5: Gonad development in Nodipecten subnodosus from December 1999 to June 2000 (adapted from Racotta et al., 2003)

\begin{tabular}{lcccccc}
\hline & Nov. 99 & Dec. 99 & Jan. 00 & Feb. 00 & Apr. 00 & Jun. 00 \\
\hline GSI (\%) & 3.7 & 2.4 & 2.9 & 3.7 & 6.4 & 7.0 \\
Immature (\%) & 68 & 73 & 100 & 53 & 6.7 & 0 \\
Maturing (\%) & 6.2 & 0 & 0 & 40 & 0 & 0 \\
Mature (\%) & 26 & 13 & 0 & 6.7 & 67 & 100 \\
Spawned (\%) & 0 & 13 & 0 & 0 & 27 & 0 \\
Oocyte diameter $(\boldsymbol{\mu m})$ & 24 & 13 & 8 & 12 & 48 & 36
\end{tabular}

GSI = Gonadosomatic index; for maturation stages, the proportion of individuals within each maturation stage assessed by histology is indicated (for more details see Racotta et al., 2003). 